\title{
RESEARCH
}

Open Access

\section{Initial absolute monocyte count as an immune biomarker for clinical response in acute myeloid leukemia with monocytic differentiation}

Ahmed Embaby ${ }^{1 *}$ D, Ayman Fathy ${ }^{1}$, Mohammad Al-Akkad ${ }^{1}$, Ahmad Baraka², Taiseer Ibrahim³ ${ }^{3}$ Nahla Zidan², Mohamed Refaat ${ }^{4}$ and Haitham Elsheikh ${ }^{1}$

\begin{abstract}
Background: Absolute monocyte count (AMC) correlates with survival outcomes in various hematologic malignancies. However, its role in myeloid malignancies including AML needs to be highlighted. So, this prospective cohort study aimed to assess the effect of AMC on the treatment outcome and survival in a 56 adult de novo AML patients with monocytic differentiation, admitted to the Clinical Hematology Unit, Internal Medicine Department, in a tertiary referral hospital in Egypt, from July 2016 to June 2019.

Results: The initial AMC was measured either by manual differential or the hematology automatic analyzer Sysmex XN-2000 and patients were classified by using receiver operating characteristic curve into two groups monocytopenic $\left(\leq 4 \times 10^{9} / \mathrm{L}\right)$ and non-monocytopenic $\left(>4 \times 10^{9} / \mathrm{L}\right)$ group; including $24(42.9 \%)$ and $32(57.1 \%)$ patients, respectively. After a median follow up period of 7.7 (range 0.5-33.2) months, the monocytopenic group was associated with a significantly higher $C R$ rate $(P=0.019)$, with a lower death as well as relapse and early relapse rates $(P=0.011,0.033$, and 0.002 , respectively). Moreover, low initial AMC along with intensive induction were independently associated with complete response to induction chemotherapy with HR, 5.04 [1.37-18.58], $P=0.015$, and $5.67[1.48-21.71], P=0.011$, respectively by using the multivariate logistic regression model. Regarding survival, the monocytopenic group was associated with a better 3-year disease-free survival rate $(P=0.011)$ in univariate Cox regression only but did not reach significance in the multivariate model and did not affect the overall survival as well.

Conclusion: Initial AMC was found to be an independent prognostic immune biomarker for treatment response in AML patients with monocytic differentiation. However, it did not appear as an independent predictor of survival in a multivariate analysis.
\end{abstract}

Keywords: Acute myeloid leukemia, Monocytic differentiation, Immune biomarker, Response, Absolute monocyte count

\footnotetext{
* Correspondence: Dr.embaby@yahoo.com; Dr.embaby@zu.edu.eg

${ }^{1}$ Clinical Hematology Unit, Internal Medicine Department, Faculty of

Medicine, Zagazig University, Zagazig, Al-Sharika 44519, Egypt

Full list of author information is available at the end of the article
}

\section{Springer Open}

(- The Author(s). 2020 Open Access This article is licensed under a Creative Commons Attribution 4.0 International License, which permits use, sharing, adaptation, distribution and reproduction in any medium or format, as long as you give appropriate credit to the original author(s) and the source, provide a link to the Creative Commons licence, and indicate if changes were made. The images or other third party material in this article are included in the article's Creative Commons licence, unless indicated otherwise in a credit line to the material. If material is not included in the article's Creative Commons licence and your intended use is not permitted by statutory regulation or exceeds the permitted use, you will need to obtain permission directly from the copyright holder. To view a copy of this licence, visit http://creativecommons.org/licenses/by/4.0/. 


\section{Background}

Acute myeloid leukemia (AML) is the most common acute leukemia in adults, accounting for approximately $78.3 \%$ of cases in this group, $1.2 \%$ of all cancers, and $34.7 \%$ of all leukemias; approximately 21,450 new cases of AML have been diagnosed annually in the USA [1].

The advent of novel therapies has significantly changed the AML outcome. However, AML remains largely incurable with a heterogeneous response to treatment [2]. Scant data are available on the contribution of the tumor microenvironment (TME) reflected in the circulating monocytes as a prognostic indicator for survival in AML [3]. Absolute monocyte count (AMC) correlates with survival outcome in lymphoma subtypes [4-6], multiple myeloma [7], and chronic lymphocytic leukemia [8]. Monocytes are key components of the innate immune system with dramatic increase with certain hematologic malignancies, particularly clonal monocytosis, and monocytic or myelomonocytic leukemia $[9,10]$. Yet, their role needs to be defined in myeloid malignancies especially in AML with monocytic differentiation which includes French-American-British (FAB) M4 and M5 subtypes and shows distinct clinical features, such as the high risk of extramedullary disease, high leukocyte count, and coagulation abnormalities [11]. Accordingly, we assessed the effect of initial AMC on the treatment outcome and survival in AML patients with monocytic differentiation.

\section{Methods}

\section{Patients}

The study was designed to prospectively evaluate a cohort of 56 newly diagnosed adult patients having primary AML with monocytic differentiation with the exclusion of acute promyelocytic leukemia. All were 18-year-old or older with good performance status (ECOG-PS) [12], and treated at the Clinical Hematology Unit in a tertiary referral hospital in Egypt, from July 2016 to June 2019.

\section{Diagnosis and classification}

The FAB classification [13], WHO 2016 criteria [14], and the International System for Human Cytogenetic Nomenclature [15] were the basis for AML diagnosis and subtyping using the morphological, immunophenotypic, and cytogenetic characteristics of leukemic blasts. In accordance with the Declaration of Helsinki, we collected written informed consent from each patient before starting the study with the agreement of our university Institutional Review Board.

\section{Data collection}

We gathered patients' clinical and laboratory data like age, gender, hemogram namely total leucocytic and monocytic counts, hemoglobin, platelet count, and the percentage of circulating and bone marrow (BM) blast cells; TLC and its differential including AMC were determined by hematology automatic analyzer Sysmex XN-2000 (Sysmex, Kobe, Japan) and confirmed by manual differential in cases of abnormal values (flagged values) or very low count that could not be detected by the device.

\section{Treatment plan}

All patients were given induction chemotherapy by an anthracycline and cytarabine-based induction chemotherapy regimen; with high-intensity therapy, an induction $3+$ 7 regimen consisting of continuous infusion cytarabine $\left(100 \mathrm{mg} / \mathrm{m}^{2}\right)$ daily for seven consecutive days combined with 3 days of doxorubicin $\left(25 \mathrm{mg} / \mathrm{m}^{2}\right)$. Elder patients were treated by low-intensity therapy; lower dose chemotherapy or hypomethylation agents. Patients who achieved complete remission received post-induction consolidation therapy which is comprised of three to four courses of high-dose cytarabine (1-2 g/m $\mathrm{m}^{2}$ every $12 \mathrm{~h}$ on days 1,3 , and 5; total, $12 \mathrm{~g} / \mathrm{m}^{2}$ ) [16].

\section{Criteria for therapy outcomes}

Response to induction therapy was assessed after one or two courses of chemotherapy. Patients are considered to be in complete remission (CR) state if their BM blasts were below $5 \%$ along with evidence of the maturation of cell lines and normalization of peripheral blood (PB) counts and no evidence of extramedullary leukemia [17]. Primary induction failure (PIF) was defined as not achieving CR within two cycles of chemotherapy. Whereas, patients with early death (ED) were those who die in the first 30 days after initiating chemotherapy [18]. Hematological relapse was considered when more than $5 \%$ blasts were seen in BM aspirates or the appearance of extramedullary leukemia, while early relapse was considered if it occurred within 6 months of CR. Regarding survival, we calculated disease-free survival (DFS) from the CR date to the date of relapse or death, and overall survival (OS) from the initial diagnosis date to the time of death or last visit.

\section{Follow-up plan}

After completion of consolidation, clinical and laboratory assessments including complete blood count (CBC), with blood smear, were done monthly for 2 years, then quarterly or biannually onward till the study came to an end. BM aspiration and biopsy only done if the peripheral smear is abnormal or cytopenias develop to rule-out relapse as recommended by the NCCN guidelines [19]. Patients who underwent allogeneic hematopoietic cell transplantation (HCT) were censored at the time of transplantation. 


\section{Statistical analysis}

A receiver operating characteristic (ROC) curve indicated that the sum of sensitivity and specificity reached a maximum for the value of AMC when $4 \times 10^{9} / \mathrm{L}$ was used as a cutoff point for survival outcome as binary endpoints and subsequently this cutoff treated as a binary variable to group patients into monocytopenic $\left(\mathrm{AMC} \leq 4 \times 10^{9} / \mathrm{L}\right)$ or non-monocytopenic $(\mathrm{AMC}>4 \times$ $\left.10^{9} / \mathrm{L}\right)$ groups. Shapiro test was applied to test data for normal distribution. Chi-square or Fisher's exact tests were utilized to compare qualitative variables, while quantitative non-parametric variables were compared by the Mann-Whitney test. Spearman's Rho test was used for linear correlation. Furthermore, independent predictors for the response were determined by enter multivariate logistic regression analysis model. Kaplan-Meier analyzer was used to calculate the OS and DFS with the log-rank test to compare survival curves. Patients undergoing allogeneic HCT were censored at the time of transplantation and the Cox-proportional hazards model was used for univariate and multivariate analysis. All tests were two-sided and a statistically significant difference was reached if $P$ value $\leq 0.05$. All statistical analyses were done using MedCalc Statistical Software (MedCalc16.4., Ostend, Belgium) and Statistical Package for Social Sciences (SPSS 20 Inc. Chicago, IL, USA).

\section{Results}

Fifty-Six previously untreated adult patients with de novo AML with monocytic differentiation were classified according to their initial AMC (Fig. 1) into 2 groups monocytopenic $\left(\leq 4 \times 10^{9} / \mathrm{L}\right)$ and non-monocytopenic $\left(>4 \times 10^{9} / \mathrm{L}\right)$, including $24(42.9 \%)$ and $32(57.1 \%)$ patients, respectively (Table 1 ).

\section{Baseline characteristics}

The median age was 46 years (range, 19-75 years), with $50 / 56(89.3 \%)$ patients were $\leq 60$ years of age and 6/56 $(10.7 \%)$ were $>60$ years. Most of them had PS range from 0 to $1,46 / 56(82.1 \%)$ with male-to-female ratio of [1:1]. The median initial TLC of the entire cohort was $20 \times 10^{9} / \mathrm{L}$ (range, $1.7-152.5 \times 10^{9} / \mathrm{L}$ ), $7 \mathrm{~g} / \mathrm{dL}$ for

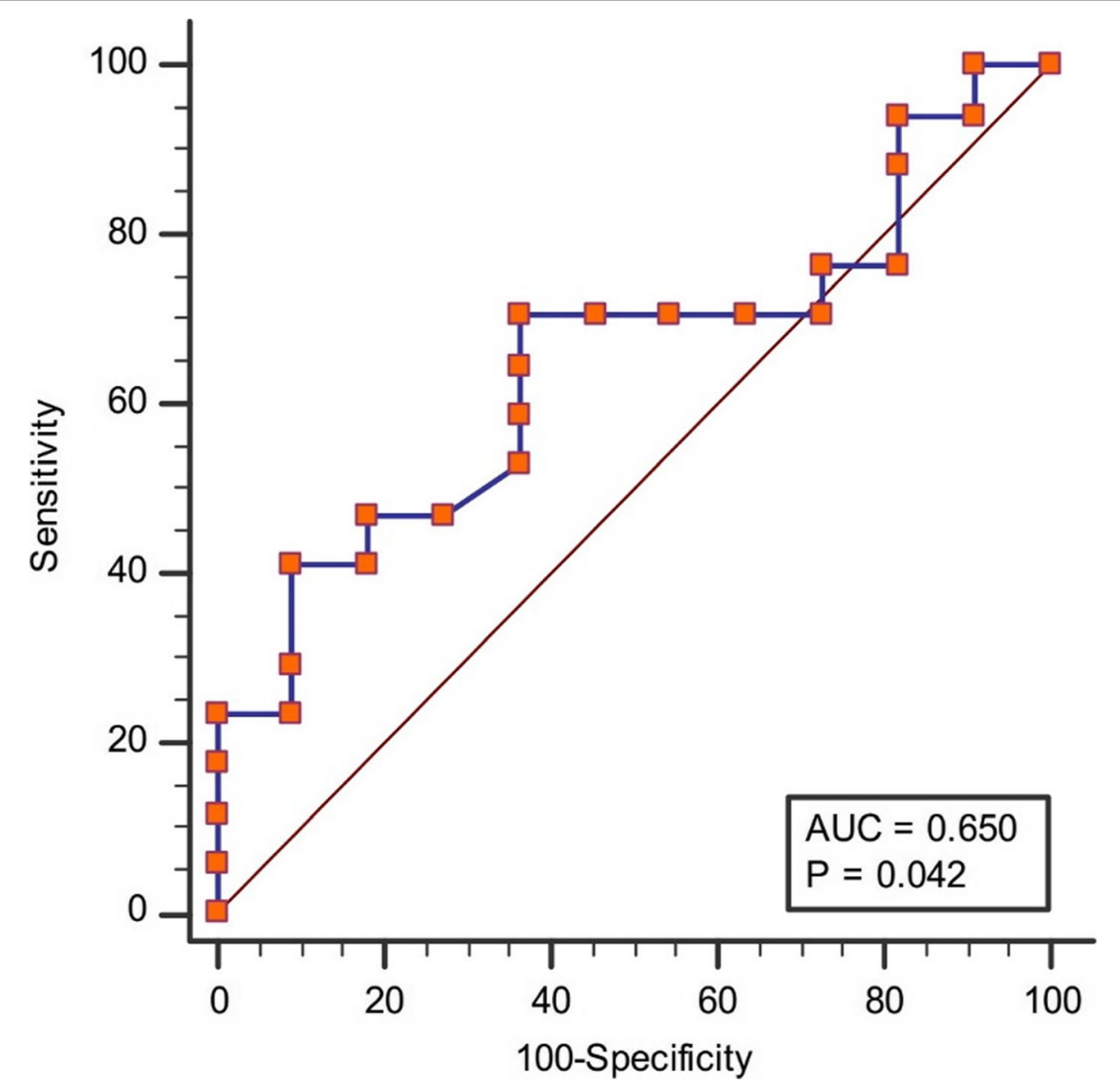

Fig. 1 Initial AMC cut-off point: receiver operating characteristic curve (ROC) for initial AMC (absolute monocyte count) level for survival analysis, AMC at cutoff $>4 \times 10^{9} / \mathrm{L}$ had an AUC of $0.65(95 \% \mathrm{Cl} 0.511$ to 0.772$)$ with a sensitivity of $70.59 \%(95 \% \mathrm{Cl} 52.5-84.9 \%)$ and a specificity of $63.64 \%$ $(95 \% \mathrm{Cl} 40.7-82.8 \%), P=0.042$ 
Table 1 Patients' clinical characteristics and outcome [median (range) or $n(\%)$ ] in both groups

\begin{tabular}{|c|c|c|c|c|c|}
\hline \multirow[t]{3}{*}{ Parameters } & & \multicolumn{2}{|l|}{ Groups } & \multirow[t]{3}{*}{ Total $N=56$} & \multirow[t]{3}{*}{$P$ value } \\
\hline & & \multirow{2}{*}{$\begin{array}{l}\text { Monocytopenic } \\
N=24\end{array}$} & \multirow{2}{*}{$\begin{array}{l}\text { Non-Monocytopenic } \\
N=32\end{array}$} & & \\
\hline & & & & & \\
\hline Age, years & & $48(20-61)$ & $42.5(19-75)$ & $46(19-75)$ & 0.371 \\
\hline \multirow[t]{2}{*}{ Age } & $\leq 60 Y$ & $22(91.7 \%)$ & $28(87.5 \%)$ & 50 (89.3\%) & 0.618 \\
\hline & $>60 Y$ & $2(8.3 \%)$ & $4(12.5 \%)$ & $6(10.7 \%)$ & \\
\hline \multirow[t]{2}{*}{ Sex } & Female & $12(50.0 \%)$ & $16(50.0 \%)$ & $28(50.0 \%)$ & 1 \\
\hline & Male & $12(50.0 \%)$ & $16(50.0 \%)$ & $28(50.0 \%)$ & \\
\hline \multirow[t]{2}{*}{ PS } & $0-1$ & $20(83.3 \%)$ & $26(81.3 \%)$ & $46(82.1 \%)$ & 0.84 \\
\hline & $>1$ & $4(16.7 \%)$ & $6(18.8 \%)$ & 10 (17.9\%) & \\
\hline \multirow[t]{2}{*}{ FAB subtype } & M4 & $20(83.3 \%)$ & $20(62.5 \%)$ & 40 (71.4\%) & 0.088 \\
\hline & M5 & $4(16.7 \%)$ & $12(37.5 \%)$ & $16(28.6 \%)$ & \\
\hline \multirow[t]{4}{*}{ Cytogenetic Risk } & Failed & $6(25.0 \%)$ & $8(25.0 \%)$ & $14(25.0 \%)$ & 0.183 \\
\hline & Favorable & $2(8.3 \%)$ & $0(0.0 \%)$ & $2(3.6 \%)$ & \\
\hline & Intermediate & $12(50.0 \%)$ & $22(68.8 \%)$ & $34(60.7 \%)$ & \\
\hline & Unfavorable & $4(16.7 \%)$ & $2(6.3 \%)$ & $6(10.7 \%)$ & \\
\hline \multicolumn{2}{|l|}{ Intensive induction } & $16(66.7 \%)$ & $22(68.8 \%)$ & $38(67.9 \%)$ & 0.869 \\
\hline \multicolumn{2}{|l|}{ Initial TLC $\times 10^{9} / \mathrm{L}$} & $6.8(1.7-23)$ & $50(10-152.5)$ & $20(1.7-152.5)$ & $<0.001$ \\
\hline \multicolumn{2}{|l|}{ Initial AMC $\times 10^{9} / \mathrm{L}$} & $1.1(0.1-4)$ & $14.7(5.1-35.1)$ & $6.1(0.1-35.1)$ & $<0.001$ \\
\hline \multicolumn{2}{|l|}{ Initial HB g/dL } & $7(5-11)$ & $7.5(4-10)$ & $7(4-11)$ & 0.893 \\
\hline \multicolumn{2}{|l|}{ Initial PLT $\times 10^{9} / \mathrm{L}$} & $25(5-117)$ & $42(12-576)$ & $33(5-576)$ & 0.014 \\
\hline \multicolumn{2}{|l|}{ Initial PB blast $\%$} & $35(0-88)$ & $49.5(13-94)$ & $40(0-94)$ & 0.034 \\
\hline \multicolumn{2}{|l|}{ Initial BM blast \% } & $54(23-90)$ & $56(21-83)$ & $55(21-90)$ & 0.504 \\
\hline \multicolumn{2}{|l|}{ Primary induction failure } & $8(33.3 \%)$ & $18(56.3 \%)$ & $26(46.4 \%)$ & 0.089 \\
\hline \multicolumn{2}{|l|}{ Early death } & $2(8.3 \%)$ & $2(6.3 \%)$ & $4(7.1 \%)$ & 0.765 \\
\hline \multicolumn{2}{|l|}{ Complete remission } & 18(75.0\%) & $14(43.8 \%)$ & $32(57.1 \%)$ & 0.019 \\
\hline \multicolumn{2}{|l|}{ Underwent $\mathrm{HCT}$} & $10(41.7 \%)$ & $2(6.3 \%)$ & $12(21.4 \%)$ & 0.001 \\
\hline \multirow{2}{*}{\multicolumn{2}{|c|}{ Death }} & 10(41.7\%) & $24(75.0 \%)$ & $34(60.7 \%)$ & 0.011 \\
\hline & & $N=18$ & $N=14$ & Total $N=32$ & \\
\hline \multicolumn{2}{|l|}{ Relapse $^{a}$} & $6(33.3 \%)$ & $10(71.4 \%)$ & $16(50.0 \%)$ & 0.033 \\
\hline \multicolumn{2}{|l|}{ Early relapse $^{\mathrm{b}}$} & $0(0.0 \%)$ & $8(80.0 \%)$ & $8(50.0 \%)$ & 0.002 \\
\hline
\end{tabular}

PS performance status, FAB French-American-British, BM bone marrow, $P B$ peripheral blood, $T L C$ total leucocytic count, $H b$ hemoglobin, $P L T$ platelets, $H C T$ hematopoietic cell transplantation

${ }^{a}$ Relapse calculated among patients who achieved CR

${ }^{\mathrm{b}}$ Early relapse estimated among relapsed patients

hemoglobin [range, 4-11 g/dL], and $33\left[5-576 \times 10^{9} / \mathrm{L}\right]$ for platelets. Meanwhile, the median circulating PB blasts was $40 \%$ (range, 0 to $94 \%$ ), while the BM blasts were $55 \%$ (range, $21-90 \%$ ). The median initial AMC for all patients was $6.1 \times 10^{9} / \mathrm{L}$, with range $\left[0.1-35.1 \times 10^{9} /\right.$ L]. Regarding FAB classification, 40 cases were M4 (71.4\%), with median initial AMC, 4.6 [range, 0.1-35.1 $\times$ $\left.10^{9} / \mathrm{L}\right]$, and $16(28.6 \%)$ were M5\%, with median AMC, 15.8 [range, $0.4-29.4 \times 10^{9} / \mathrm{L}$ ], $P=0.046$ (Fig. 2). Furthermore, a direct significant linear correlation was noticed between the initial AMC and TLC $(P<0.001)$, but not the other parameters (Fig. 3 and Table 2).
Chromosomal analysis revealed that two (3.6\%) patients had a favorable cytogenetic profile and 34 (60.7\%) had an intermediate while six (10.7\%) patients had unfavorable cytogenetics. Failure to attain cytogenetics was noticed in 14 (25.0\%) patients. After initial workup, 38 (67.9\%) patients received intensive induction chemotherapy and $18(32.1 \%)$ patients were candidates only for less intensive chemotherapy. Moreover, the non-monocytopenic group was significantly associated with higher $\mathrm{AMC}$, platelet (PLT) count, and PB blast $(P<0.001, P<0.001, P=0.014$, and $P=0.034$, respectively). However, no significant statistical difference was found with other variables (Table 1). 


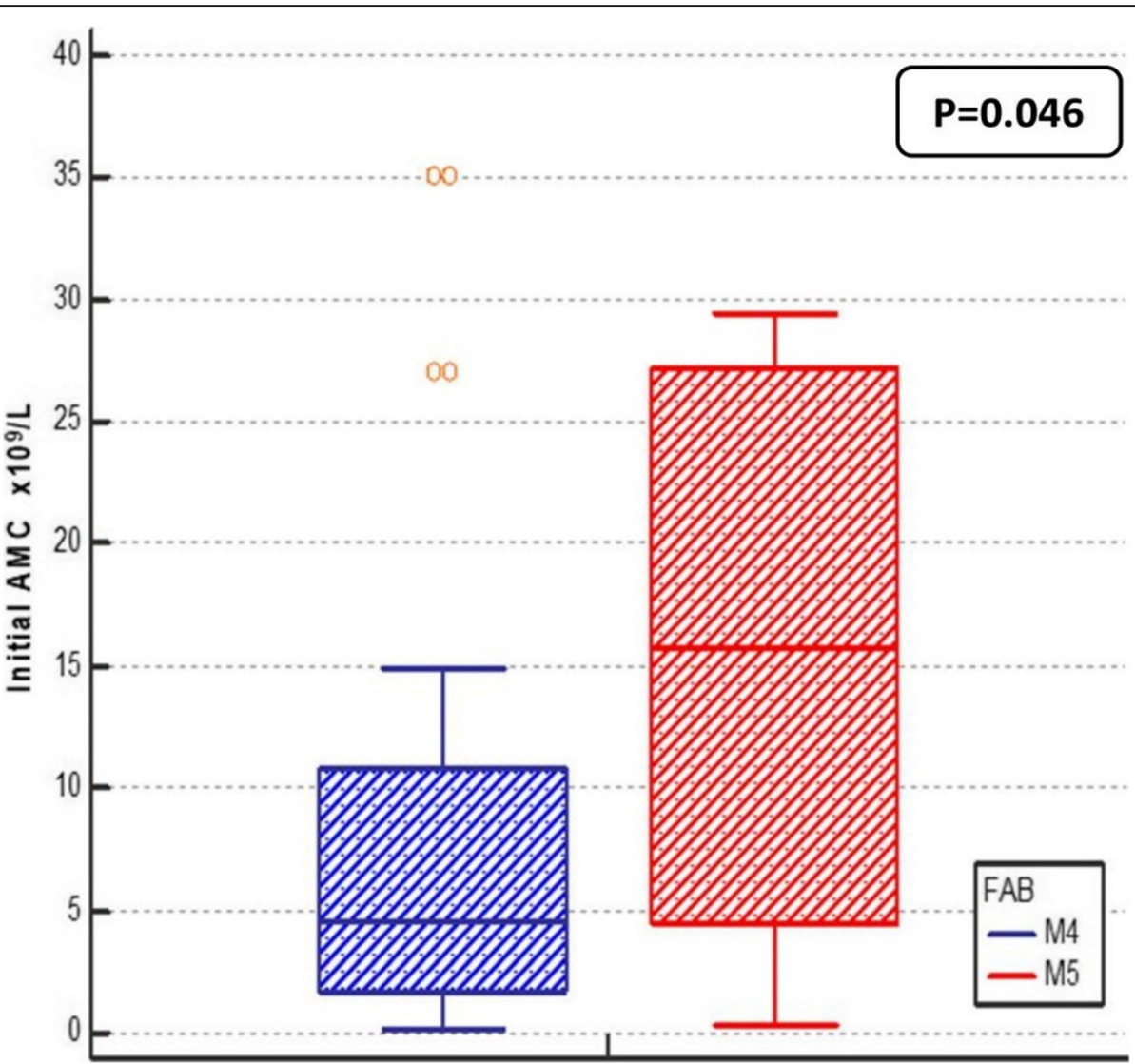

Fig. 2 Comparison between initial AMC level in AML-subgroups: Box-plot diagram represents the range of initial AMC (absolute monocyte count) level as regard FAB subtype, $P=0.046$; the upper and lower line in each box represents the 75 th and 25th percentile respectively while the line through each box indicates the median. Whiskers represent the range between the minimum and maximum values excluding outliers (rounded markers)

\section{Remission induction outcome}

As shown in Table 1, 32 (57.1\%) patients achieved CR, $26(46.4 \%)$ patients did not achieve CR after at least two cycles of induction therapy (PIF), and four patients (7.1\%) died early in the first 30 days of induction (early death) and by the end of follow-up, a total 34/56 (60.7\%) of patients died. On following up the cases that achieved CR, 16/32 (50.0\%) cases were relapsed, half of them relapsed within 6 months (ER), and 12 (21.4\%) patients underwent $\mathrm{HCT}$ either after $\mathrm{CR}_{1}$ in those with high-risk cytogenetics or $\mathrm{CR}_{2}$ in relapsed patients. Moreover, the monocytopenic group was associated with significantly higher $\mathrm{CR}$ and HCT rates $(P=0.019$ and 0.001 , respectively), with a significantly lower death rate as well as relapse and early relapse rates $(P=0.011,0.033$ and 0.002 , respectively). While no significant difference was found regarding PIF or ED.

\section{Response analysis}

Binary logistic regression was performed to ascertain the effects of different variables on the likelihood that participants achieved CR and only the initial AMC and intensive induction therapy were independently associated with response to therapy in multivariate analysis with $\mathrm{HR}, 5.04$ [1.37-18.58, $P=0.015]$ and $5.67[1.48-21.71, P=0.011]$, respectively (Table 3 ).

\section{Survival analysis}

Patients were followed up for a median period of 7.7 months, range (0.5-33.2 months). The 3-year overall survival rate was $0.0 \%$ with a mean OS of $11.2 \pm 1.3$ months (95\% CI 8.6-13.9 months) and the median was $10 \pm 1.6$ months (95\% CI 6.9-13.1 months) while the 3-year disease-free survival rate was $0.0 \%$ with a mean of $12.1 \pm 1.5$ months (95\% CI 9-15.1) and the median was $9.3 \pm 1.9$ months (95\% CI 5.5-13.1) (Table 4 and Fig. 4a, b). Kaplan-Meier analysis showed no statistical difference in 3-year OS between the monocytopenic and non-monocytopenic group or M4 and M5 subtypes $(P=0.076$ and 0.725 , respectively) (Table 4 and Fig. 5a, b). Moreover, a statistical difference in 3-year DFS was found between both groups and M4 and M5 subgroups $(P=0.011$, and 0.001, respectively) (Fig. 6a, b). 


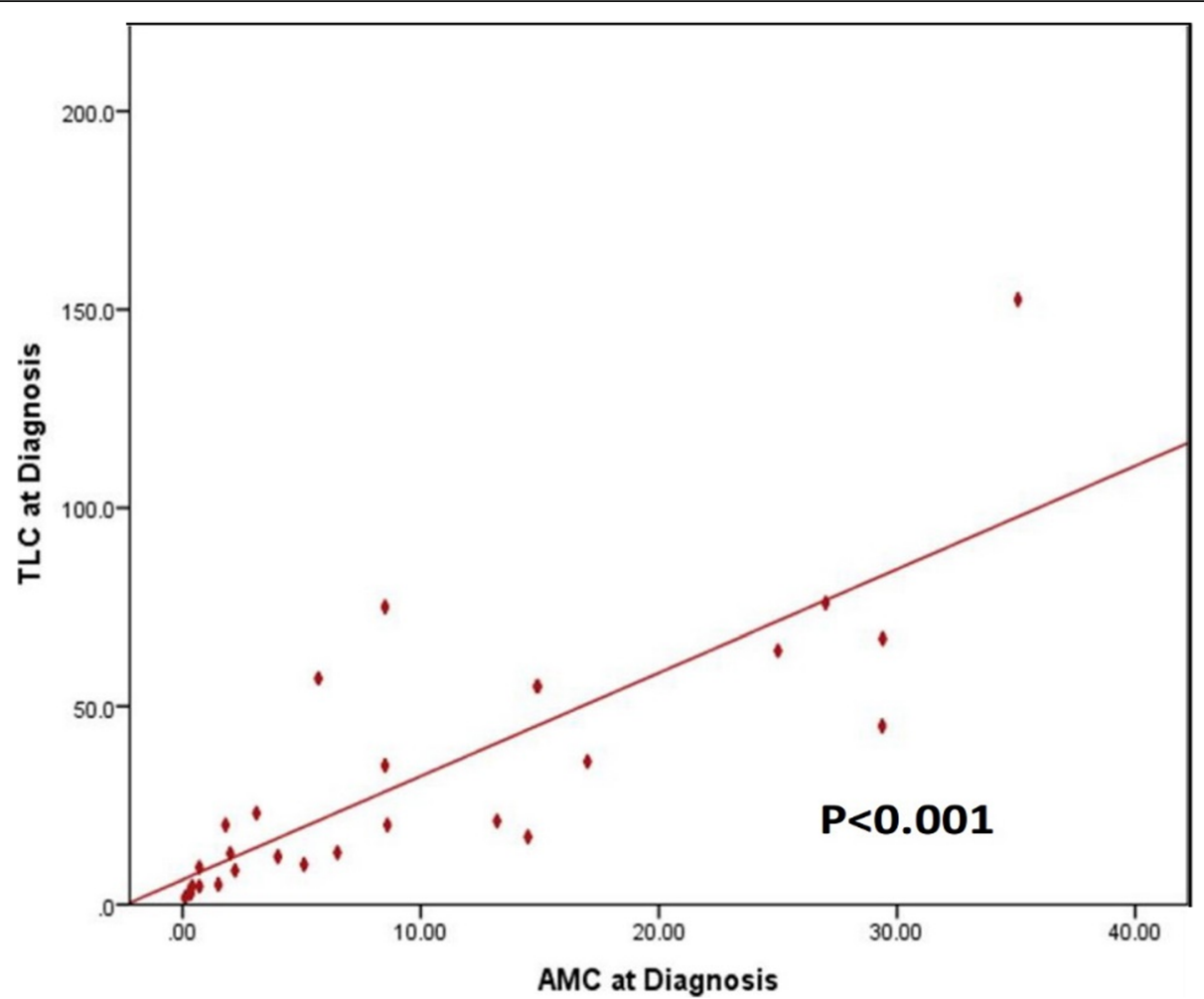

Fig. 3 Linear correlation between the initial AMC (absolute monocyte count) and TLC (total leucocyte count)

The Cox proportional hazards model evaluating the different variables affecting survival was summarized in Table 5 and showed that in univariate analysis, the following clinical parameters were significantly associated with OS, PIF, and initial platelet count $(P<0.001$ and 0.002 , respectively). However, in multivariate analysis, only PIF was independently associated with shorter OS (HR; 6.9 [2.8-17.8], $P<0.001$ ). Regarding the DFS, initial AMC was found to have survival impact only in the univariate module $(P=0.021)$ but, it did not achieve significance in multivariate analysis.

Table 2 correlation between the Initial $\mathrm{AMC} \times 10^{9} / \mathrm{L}$ and other studied parameters

\begin{tabular}{lll}
\hline Variable & Initial AMC $\times 10^{9} / \mathrm{L}$ & \\
\cline { 2 - 3 } & $r$ & $P$ \\
\hline Age & -0.001 & 0.997 \\
PS & +0.119 & 0.388 \\
Initial PB blast $\%$ & +0.202 & 0.16 \\
Initial BM blast $\%$ & -0.165 & 0.242 \\
Initial TLC $\times 10^{9} / \mathrm{L}$ & +0.881 & $<0.001$ \\
Initial Hb $\mathrm{g} / \mathrm{dL}$ & -0.096 & 0.482 \\
Initial PLT $\times 10^{9} / \mathrm{L}$ & +0.16 & 0.24 \\
\hline
\end{tabular}

$r$ correlation coefficient, $A M C$ absolute monocyte count, $P S$ performance status, $B M$ bone marrow, $P B$ peripheral blood, $T L C$ total leucocytic count, $H b$ hemoglobin, PLT platelets

\section{Discussion}

An accurate prognostic assessment is fundamental to provide better clinical management and enhance the outcome of AML especially in an important subgroup like those with monocytic differentiation that carry high-risk features, including higher tumor burden represented in the brisk increase in leukocyte count, extramedullary disease, and coagulation abnormalities [11]. Furthermore, peripheral blood monocytes, the mirror of the immunosuppressive AML microenvironment [20, 21], have been tested as a prognostic factor for different types of hematological malignancies including AML [3-8]. However, that role was not clearly studied in M4/M5 patients. So, in our study, we shed some light on the significance of the initial AMC in a 56 cohort of newly diagnosed AML patients with monocytic differentiation.

To the best of our knowledge, we are the first prospective study to investigate the significance of the initial AMC in this subset of patients and our main findings revealed that in AML patients with monocytic differentiation, the monocytopenic group (defined by ROC curve as those with AMC level $\leq 4 \times 10^{9} / \mathrm{L}$ ) was significantly associated with higher CR rates, and lower death, relapse, and early relapse rates, with longer DFS.

Few published studies investigated the prognostic value of AMC in AML patients; one main study was 
Table 3 Univariate and multivariable logistic regression analyses for response to therapy (achievement of CR)

\begin{tabular}{|c|c|c|c|c|}
\hline \multirow[t]{2}{*}{ Covariates } & \multicolumn{2}{|l|}{ Univariate analysis } & \multicolumn{2}{|c|}{ Multivariate analysis } \\
\hline & OR $(95 \% \mathrm{Cl})$ & $P$ & OR $(95 \% \mathrm{Cl})$ & $P$ \\
\hline Age $(>60 Y$ vs. $\leq 60 Y)$ & $3.00(0.50-17.95)$ & 0.229 & & \\
\hline Sex (Male vs. Female) & $1.00(0.35-2.88)$ & 1 & & \\
\hline PS (> 1 Y vs. $\leq 1)$ & $2.33(0.58-9.43)$ & 0.234 & & \\
\hline FAB (M4 vs. M5) & $0.91(0.29-2.82)$ & 0.869 & & \\
\hline Intensive induction (yes vs no) & $4.33(1.31-14.31)$ & 0.016 & $5.67(1.48-21.71)$ & 0.011 \\
\hline Initial peripheral blast \% & $1.00(0.98-1.02)$ & 0.948 & & \\
\hline Initial bone marrow blast \% & $1.00(0.97-1.02)$ & 0.779 & & \\
\hline Initial TLC $\times 10^{9} / \mathrm{L}$ & $1.02(1.00-1.04)$ & 0.069 & & \\
\hline Monocytopenic (yes vs. no) & $3.86(1.21-12.28)$ & 0.022 & $5.04(1.37-18.58)$ & 0.015 \\
\hline Cytogenetics (favorable vs others) & $0.00(0.0001-0.002)$ & 0.999 & & \\
\hline
\end{tabular}

PS performance status, $F A B$ French-American-British, $T L C$ total leucocytic count, $O R$ odds ratio, 95\% Cl 95\% confidence interval

done by Feng and coworkers, who found that high pretreatment AMC was associated with worse OS as compared with normal AMC patients [3]. This disagreement with our findings might be due to several factors like they used $0.8 \times 10^{9} / \mathrm{L}$ as the cut-off point of AMC for survival outcome of AML patients obtained by the ROC curve. They included different FAB subtypes, unlike our study which focused on M4/M5 patients. Moreover, they carried out their study on Chinese patients, unlike ours which were all Egyptians, thus these racial/ ethnic differences not only impact the AML survival rates but also the distinct monocyte behavior involving pro- and anti-tumor immunity, tumor advancement, and prognosis. In addition to that, they used a larger sample size with a longer follow up period, despite the retrospective design of the study that leads to selection bias.

Also, a recent study reported that high AMC was associated with lower CR rates, shorter OS, and leukemia-free survival in AML patients [22]. Despite having similar findings with our study, they were different in the retrospectively selected population that included all subtypes of AML together with M4/M5. Besides using different cut off value of the AMC. On the other hand, Bar and his colleagues reported that the pretreatment $\mathrm{AMC}$ was not associated with any statistically significant difference regarding OS or DFS rates [23]. This discrepancy with our findings might be owing to the inclusion of secondary AML along with all FAB subtypes and the retrospective selection of patients in remission in their study.

Remarkably in our M5 subgroup, higher initial AMC levels, as well as poor DFS rates were noticed compared to M4 subgroup, that could be explained by a different study that recognized higher TGF- $\beta$ levels in M5 than M4 which play a physiologic role in monocyte maturation, differentiation, and recruitment in leukemiaassociated macrophages (LAMS) with subsequent poor outcome [21, 24].

The intrinsic relationship between peripheral monocytes and clinical outcomes in patients with AML derived mainly from monocyte-derived mononuclear phagocytes

Table 4 The 3-year overall and Disease-free survival rates in both groups

\begin{tabular}{|c|c|c|c|c|c|c|}
\hline \multirow[t]{3}{*}{ Groups } & \multirow{3}{*}{$\begin{array}{l}\text { Survival } \\
\text { rate } \%\end{array}$} & \multirow[t]{3}{*}{$P$ value } & \multicolumn{4}{|c|}{ Survival time, months } \\
\hline & & & \multicolumn{2}{|l|}{ Mean } & \multicolumn{2}{|l|}{ Median } \\
\hline & & & Estimate \pm SE & $95 \% \mathrm{Cl}$ & Estimate \pm SE & $95 \% \mathrm{Cl}$ \\
\hline \multicolumn{7}{|l|}{ The 3-years OS\% } \\
\hline Monocytopenic & $0.00 \%$ & 0.076 & $11.7 \pm 1.4$ & $8.9-14.4$ & $16.3 \pm 0$ & - \\
\hline Non-monocytopenic & $13.40 \%$ & & $9.6 \pm 1.5$ & $6.6-12.5$ & $8.5 \pm 2.1$ & $4.3-12.7$ \\
\hline Overall & $0.00 \%$ & & $11.2 \pm 1.3$ & $8.6-13.9$ & 10 & $6.9-13.1$ \\
\hline \multicolumn{7}{|l|}{ The 3-years DFS\% } \\
\hline Monocytopenic & $41.70 \%$ & 0.011 & $11 \pm 0.6$ & $9.8-12.1$ & $12 \pm 1.9$ & $8.1-15.7$ \\
\hline Non-monocytopenic & $0.00 \%$ & & $9 \pm 2.5$ & $3.5-13.6$ & $6 \pm 1.2$ & $3.5-8.5$ \\
\hline Overall & $0.00 \%$ & & $12.1 \pm 1.5$ & $9-15.1$ & $9.3 \pm 1.9$ & $5.5-13.1$ \\
\hline
\end{tabular}

OS overall survival, DFS disease-free survival, SE std. error, $95 \%$ Cl 95\% confidence interval, $P$ value of Log rank test 


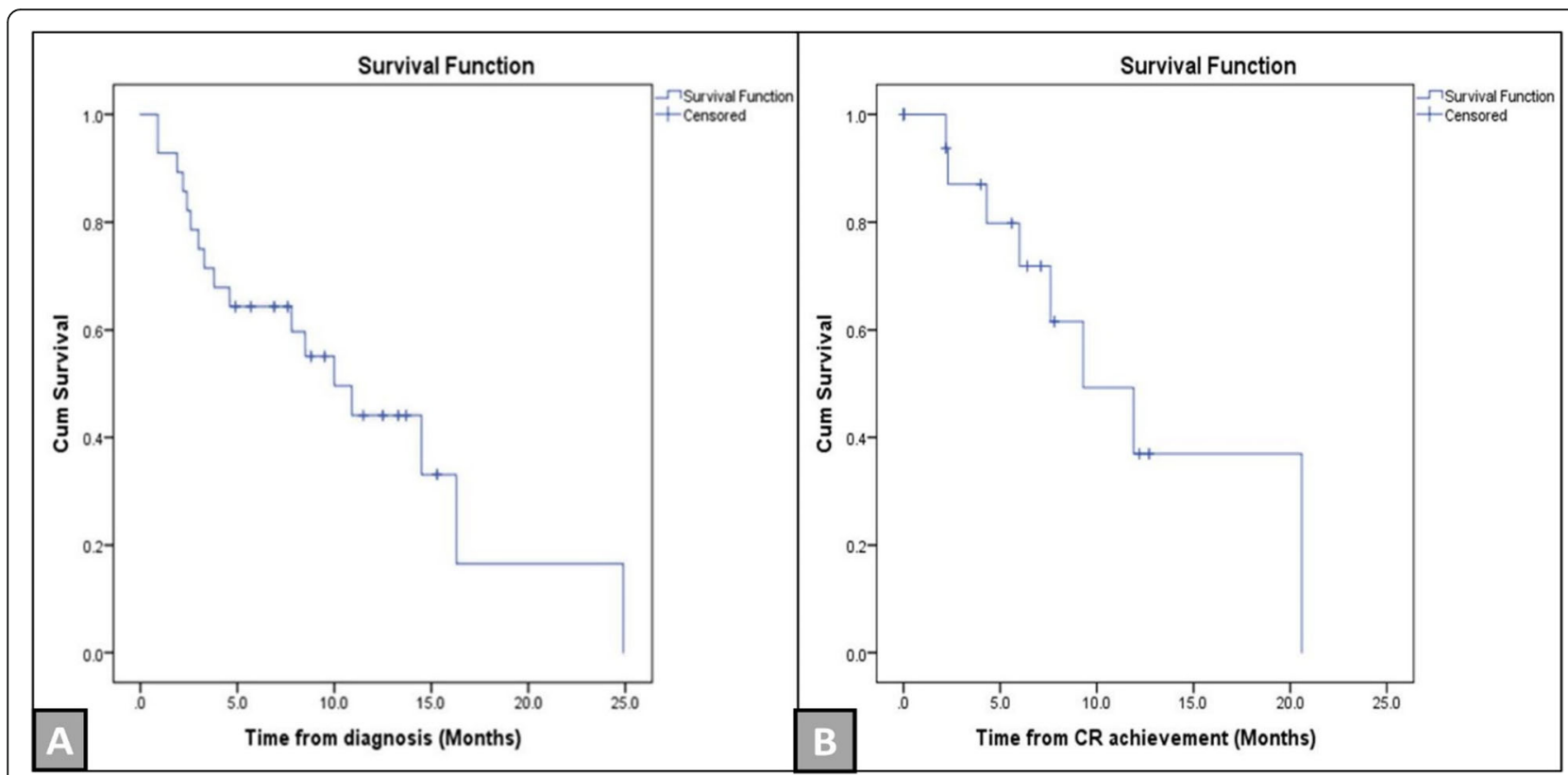

Fig. 4 Survival analysis of the studied population. a The 3-year overall survival. b The 3-year disease-free survival

like myeloid-derived suppressor cells (MDSCs), macrophages, and monocytes, the latter are vital constituent of the inflammatory response, might directly enhance malignant cell growth by the generation of numerous proinflammatory cytokines [25]. Besides, various laboratory-based researches have adopted the principle that tumor-associated macrophages (TAMs), evolved from peripheral blood monocytes, could promote systemic immunosuppression and significantly contribute to tumor cell invasion, migration, and angiogenesis [26]; even more, high AMC seems to be associated with an increased TAMs density [21]. Accordingly, an elevated AMC level may be a surrogate for higher monocytes and TAMs within the TME subsequently protect the AML cells and eventually carry a poor prognosis for those patients.

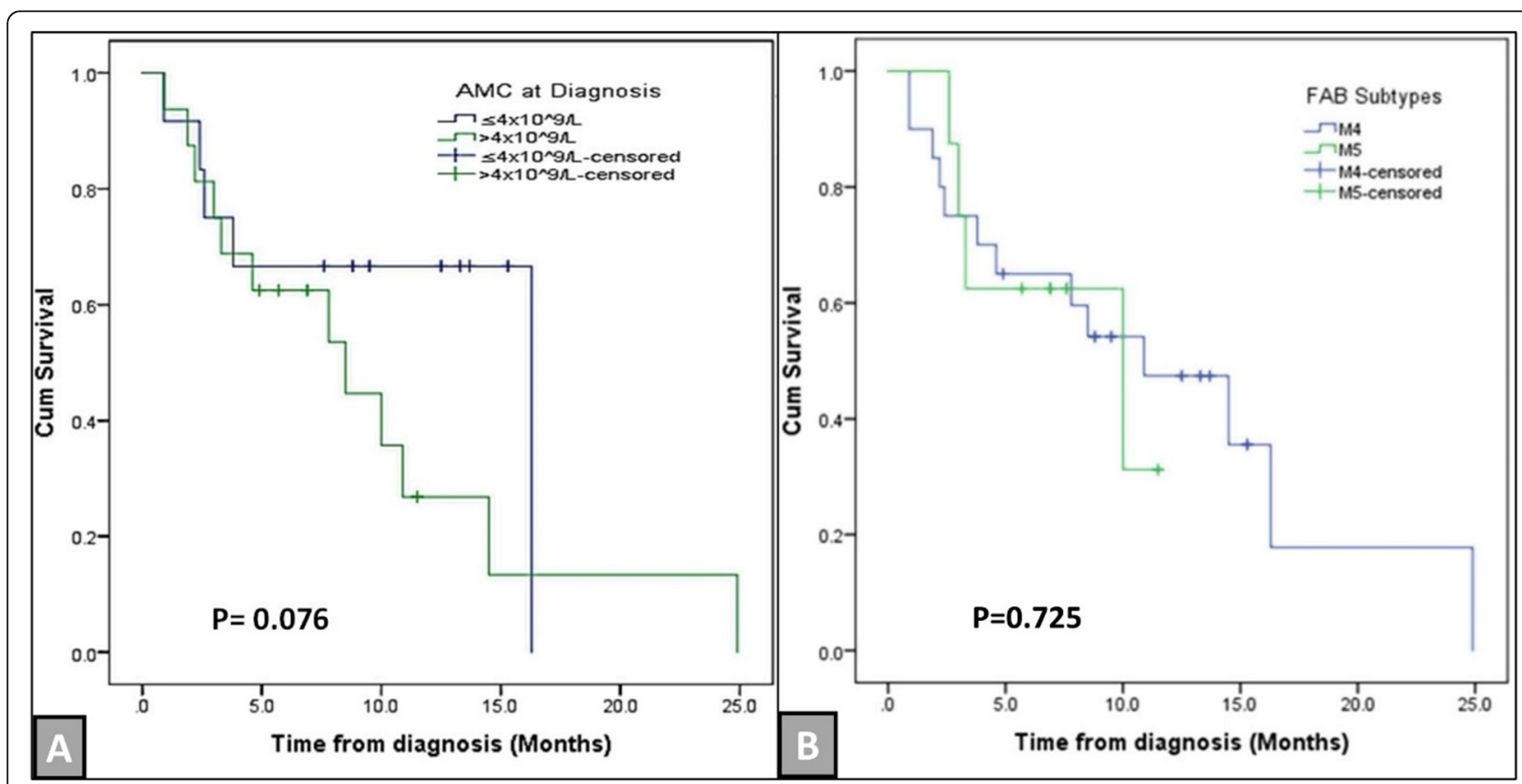

Fig. 5 The 3-year overall survival analysis in different subgroups. a The 3-year overall survival as regard the initial AMC (absolute monocyte count) level. $\mathbf{b}$ The 3-year overall survival as regard the AML-subgroups 


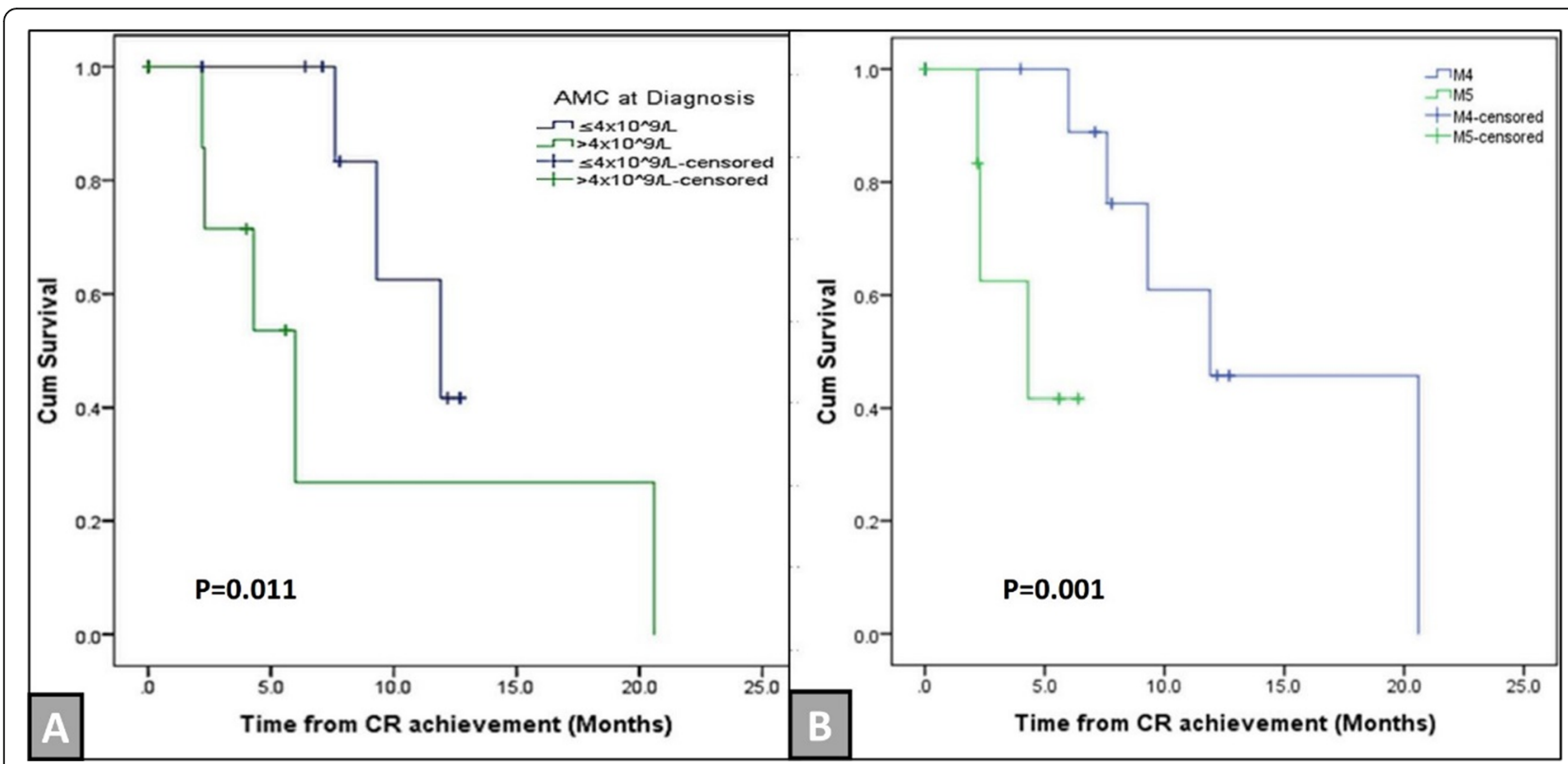

Fig. 6 The 3-year disease-free survival analysis in different subgroups. a The 3-year disease-free survival as regard the initial AMC (absolute monocyte count) level. $\mathbf{b}$ The 3-year disease-free survival as regard the AML-subgroups

One of the limitations in our study is that our findings are derived solely from the $\mathrm{CBC}$ used in routine clinical practice, thus we are unable to determine phenotypic and functional changes within the monocyte-derived cell population that may have survival impact. So, we should be prudent when elucidating the results of this study, or probably our results might not be generalizable to other populations. Moreover, the prognostic role of the initial AMC as regard DFS was found only in the univariate analysis. Thus, it should be revalidated in the multivariate context including genetic information and monocyte subpopulations in the further prospective studies.

\section{Conclusions}

This is the first prospective study to evaluate the relationship between the initial AMC and the outcome of AML patients with monocytic differentiation. Despite correlations of low AMC with DFS in univariate analysis,

Table 5 Univariate and multivariate Cox-regression analyses for overall and disease-free survival

\begin{tabular}{|c|c|c|c|c|c|c|c|c|}
\hline \multirow[t]{3}{*}{ Covariates } & \multicolumn{4}{|l|}{ Overall survival } & \multicolumn{4}{|c|}{ Disease-free survival } \\
\hline & \multicolumn{2}{|l|}{ Univariate analysis } & \multicolumn{2}{|c|}{ Multivariate analysis } & \multicolumn{2}{|l|}{ Univariate analysis } & \multicolumn{2}{|c|}{ Multivariate analysis } \\
\hline & $\mathrm{HR}(95 \% \mathrm{Cl})$ & $P$ & $\mathrm{HR}(95 \% \mathrm{Cl})$ & $P$ & $\mathrm{HR}(95 \% \mathrm{Cl})$ & $P$ & $\mathrm{HR}(95 \% \mathrm{Cl})$ & $P$ \\
\hline Age (>60Y vs. $\leq 60 Y)$ & $0.80(0.28-2.31)$ & 0.682 & & & $0.04(0.00-36.60)$ & 0.35 & & \\
\hline Sex (M vs. F) & $1.29(0.63-2.66)$ & 0.485 & & & $1.89(0.58-6.23)$ & 0.293 & & \\
\hline PS $(>1 Y$ vs. $\leq 1)$ & $1.24(0.50-3.04)$ & 0.642 & & & $0.04(0.00-23.31)$ & 0.317 & & \\
\hline PIF (yes vs. no) & $7.8(3.2-19.2)$ & $<0.001$ & $6.9(2.7-17.9)$ & $<0.001$ & $2.5(0.52-11.92)$ & 0.296 & & \\
\hline FAB (M4 vs. M5) & $0.74(0.36-1.52)$ & 0.412 & & & $0.61(0.19-1.98)$ & 0.409 & & \\
\hline Intensive induction (yes vs. no) & $0.64(0.31-1.32)$ & 0.226 & & & $4.83(0.99-23.59)$ & 0.052 & $6.98(0.69-70.77)$ & 0.1 \\
\hline Initial PB blast \% & $1.00(0.99-1.02)$ & 0.552 & & & $1.02(1.00-1.04)$ & 0.055 & $1.05(0.99-1.10)$ & 0.092 \\
\hline Initial BM blast \% & $1.00(0.99-1.02)$ & 0.693 & & & $1.00(0.98-1.03)$ & 0.797 & & \\
\hline Initial TLC $\times 10^{9} / \mathrm{L}$ & $1.00(0.99-1.01)$ & 0.989 & & & $1.02(1.00-1.04)$ & 0.058 & & \\
\hline Cytogenetics (favorable vs. others) & $0.05(0.00-56.25)$ & 0.394 & & & $0.04(0.00-36.60)$ & 0.35 & & \\
\hline Monocytopenic (yes vs. no) & $1.91(0.90-4.04)$ & 0.091 & $1.03(0.46-2.34)$ & 0.941 & $3.65(1.22-10.93)$ & 0.021 & $1.26(0.10-15.43)$ & 0.856 \\
\hline Initial PLT $\times 10^{9} / \mathrm{L}$ & $1.00(1.00-1.01)$ & 0.002 & $1.00(0.99-1.04)$ & 0.338 & $0.99(0.97-1.01)$ & 0.686 & & \\
\hline Initial Hb g/dL & $1.03(0.85-1.25)$ & 0.75 & & & $1.06(0.77-1.47)$ & 0.715 & & \\
\hline
\end{tabular}

PS performance status, FAB French-American-British, PIF primary induction failure, $B M$ bone marrow, $P B$ peripheral blood, $T L C$ total leucocytic count, $H b$ hemoglobin, PLT platelets, HR hazard ratio, $95 \% \mathrm{Cl} 95 \%$ confidence interval 
AMC did not appear as an independent predictor of survival outcome in multivariate analysis. Moreover, the initial AMC was found to be an independent prognostic factor for response to induction chemotherapy in those populations. Finally, before generalization of these findings, larger prospective multicenter studies considering racial and genetic information and monocyte subpopulations are required.

\begin{abstract}
Abbreviations
AM: Absolute monocyte count; AML: Acute myeloid leukemia; BM: Bone marrow; CBC: Complete blood count; Cl: Confidence interval; CR: Complete remission; DFS: Disease-free survival; ED: Early death; FAB: French-AmericanBritish; Hb: Hemoglobin; HCT: Hematopoietic cell transplantation; IL: Interleukin; LAMs: Leukemia-associated macrophages; MCP-1: Monocyte chemoattractant protein-1; MDSCs: Myeloid-derived suppressor cells; NCCN: National Comprehensive Cancer Network; NK cells: Natural killer cells; NR: No remission; OS: Overall survival; PB: Peripheral blood; PIF: Primary induction failure; PLT: Platelet; PS: Performance status; $r$ : Correlation coefficient; ROC: Receiver operating characteristic; SPSS: Statistical Package for Social Sciences; TAMs: Tumor-associated macrophages; TLC: Total leucocytic count; TME: Tumor microenvironment; TNF-a: Tumor necrosis factor-alpha; VEGF: Vascular endothelial growth factor; WHO: World Health Organization
\end{abstract}

\section{Acknowledgments}

We would like to thank the patients who participated as well as the members of the research and clinical staff at Zagazig Clinical Hematology Unit for their contribution to the care of our patients especially, Dr Shimaa A., Muhammad El Brdecy, Mohamed Yousef, and Mohamed Al-Shamy.

\section{Authors' contributions}

AE contributed in conceptualization, methodology, statistical analysis, interpreting the results, designed the figures, investigation, performed patients' clinical assessment, and follow-up as well as drafted this manuscript with help from MR and HE. AF, MA, and HE were involved in planning, organization, supervision and reviewing of the work, and the final manuscript. AB, NZ, and TI performed the measurements, Lab. and histopathologic analysis like CBC, blood smears, flowcytometry BM aspirates/ biopsy. All authors have read and approved the manuscript.

\section{Funding}

Not applicable.

\section{Availability of data and materials}

All data analyzed and generated during this study are included in this published article.

\section{Ethics approval and consent to participate}

This study has been approved by the Faculty of Medicine, Zagazig University, Institutional Review Board (IRB) for human studies (reference number is ZUIRB \#2899-7-6-2016) and the patients have signed an informed written consent.

\section{Consent for publication}

An oral consent was obtained from all participating patients to publish their data.

\section{Competing interests}

The authors declare that they have no competing interest.

\section{Author details}

${ }^{1}$ Clinical Hematology Unit, Internal Medicine Department, Faculty of Medicine, Zagazig University, Zagazig, Al-Sharika 44519, Egypt. ${ }^{2}$ Clinical Pathology Department, Faculty of Medicine, Zagazig University, Zagazig, Egypt. ${ }^{3}$ Pathology Department, Faculty of Medicine, Zagazig University, Zagazig, Egypt. ${ }^{4}$ Clinical Oncology Department, Faculty of Medicine, Zagazig University, Zagazig, Egypt.
Received: 23 April 2020 Accepted: 2 July 2020

Published online: 03 August 2020

\section{References}

1. Siegel RL, Miller KD, Jemal A. Cancer statistics. CA Cancer J Clin. 2019;69:734. https://doi.org/10.3322/caac.21551 Epub 2019 Jan 8.

2. Liersch R, Müller-Tidow C, Berdel WE, Krug U. Prognostic factors for acute myeloid leukaemia in adults-biological significance and clinical use. Br J Haematol. 2014;165:17-38.

3. Feng J, Zhang W, Wu J, Gao S, Ye H, Sun L, Chen Y, Yu K, Xing C-YY. Effect of initial absolute monocyte count on survival outcome of patients with de novo non-M3 acute myeloid leukemia. Leuk Lymphoma. 2016;57:2548-54. https://doi.org/10.3109/10428194.2016.1166491.

4. Wilcox RA, Ristow K, Habermann TM, Inwards DJ, Micallef INM, Johnston PB, Colgan JP, Nowakowski GS, Ansell SM, Witzig TE, Markovic SN, Porrata L. The absolute monocyte and lymphocyte prognostic score predicts survival and identifies high-risk patients in diffuse large-B-cell lymphoma. Leukemia. 2011;25:1502-9. https://doi.org/10.1038/leu.2011.112.

5. Wilcox RA, Ristow K, Habermann TM, Inwards DJ, Micallef INM, Johnston PB, Colgan JP, Nowakowski GS, Ansell SM, Witzig TE, Markovic SN, Porrata L. The absolute monocyte count is associated with overall survival in patients newly diagnosed with follicular lymphoma. Leuk Lymphoma. 2012;53:57580. https://doi.org/10.3109/10428194.2011.637211.

6. Porrata LF, Ristow K, Colgan JP, Habermann TM, Witzig TE, Inwards DJ, Ansell SM, Micallef IN, Johnston PB, Nowakowski GS, Thompson C, Markovic SN. Peripheral blood lymphocyte/monocyte ratio at diagnosis and survival in classical Hodgkin's lymphoma. Haematologica. 2012;97:262-9. https://doi. org/10.3324/haematol.2011.050138.

7. E. Malek, T. Dosani, R. Pinto, F. Covut, H. Akabane, J.J. Driscoll, M. De Lima, Immunologic status evaluated by the absolute lymphocyte/ monocyte ratio provides a powerful prognostic tool for newly diagnosed multiple myeloma, (2016) 1862-1862. doi.https://doi.org/10. 1182/blood.V128.22.1862.1862

8. Herishanu Y, Kay S, Sarid N, Kohan P, Braunstein R, Rotman R, Deutsch V, Ben-Ezra J, Naparstek E, Perry C, Katz BZ. Absolute monocyte count trichotomizes chronic lymphocytic leukemia into high risk patients with immune dysregulation, disease progression and poor survival. Leuk Res. 2013;37:1222-8. https://doi.org/10.1016/j.leukres.2013.07.017.

9. Ma WT, Gao F, Gu K, Chen DK. The role of monocytes and macrophages in autoimmune diseases: a comprehensive review. Front Immunol. 2019;10. https://doi.org/10.3389/fimmu.2019.01140.

10. Kenneth Kaushansky ML, Josef Prchal MML, Oliver Press LB, Caligiuri M. Williams Hematology 9th edition; 2015.

11. Döhner H, Estey EH, Amadori S, Appelbaum FR, Büchner T, Burnett AK, Dombret H, Fenaux P, Grimwade D, Larson RA, Lo-Coco F. Diagnosis and management of acute myeloid leukemia in adults: recommendations from an international expert panel, on behalf of the European LeukemiaNet. Blood. 2010;115:453-74. https://doi.org/10.1182/blood-2012-03-362608.

12. Oken MM, Creech RH, Tormey DC, Horton J, Davis TE, McFadden ET, et al. Toxicity and response criteria of the eastern cooperative oncology group. Am J Clin Oncol. 1982;5:649-55.

13. Bennett JM, Catovsky D, Daniel MT, Flandrin G, Galton DAG, Gralnick HR, Sultan C. Proposals for the classification of the acute leukaemias FrenchAmerican-British (FAB) co-operative group. Br J Haematol. 1976. https://doi. org/10.1111/j.1365-2141.1976.tb03563.x.

14. Arber DA, Orazi A, Hasserjian R, Thiele J, Borowitz MJ, Le Beau MM, et al. The 2016 revision to the World Health Organization classification of myeloid neoplasms and acute leukemia. Blood. 2016;127:2391-405. https://doi.org/ 10.1182/blood-2016-03-643544

15. Harnden DG, Klinger HP. An international system for human cytogenetic nomenclature (1985): Karger Basel etc; 1985.

16. Tefferi A, Letendre L. Going beyond $7+3$ regimens in the treatment of adult acute myeloid leukemia. J Clin Oncol. 2012;30:2425-8. https://doi.org/ 10.1200/jco.2011.38.9601.

17. Cheson BD, Bennett JM, Kopecky KJ, Büchner T, Willman CL, Estey EH, et al. Revised recommendations of the international working group for diagnosis, standardization of response criteria, treatment outcomes, and reporting standards for therapeutic trials in acute myeloid leukemia. J Clin Oncol. 2003;21:4642-9.

18. Döhner H, Estey E, Grimwade D, Amadori S, Appelbaum FR, Büchner T, Dombret H, Ebert BL, Fenaux P, Larson RA, Levine RL, Lo-Coco F, Naoe T, 
Niederwieser D, Ossenkoppele GJ, Sanz M, Sierra J, Tallman MS, Tien HF, Wei $\mathrm{AH}$, Löwenberg B, Bloomfield CD. Diagnosis and management of AML in adults: 2017 ELN recommendations from an international expert panel. Blood. 2017;129:424-47. https://doi.org/10.1182/blood-2016-08-733196.

19. Tallman MS, Wang ES, Altman JK, Appelbaum FR, Bhatt VR, Bixby D, Coutre SE, De Lima M, Fathi AT, Fiorella M, Foran JM, Hall AC, Jacoby M, Lancet J, LeBlanc TW, Mannis G, Marcucci G, Martin MG, Mims A, O'Donnell MR, Olin R, Peker D, Perl A, Pollyea DA, Pratz K, Prebet T, Ravandi F, Shami PJ, Stone RM, Strickland SA, Wieduwilt M, Gregory KM, Hammond L, Ogba N. Acute myeloid leukemia, version 3.2019. JNCCN J Natl Compr Cancer Netw. 2019; 17:721-49. https://doi.org/10.6004/jnccn.2019.0028.

20. Buggins AGS, Milojkovic D, Arno MJ, Lea NC, Mufti GJ, Thomas NSB, Hirst WJR. Microenvironment produced by acute myeloid leukemia cells prevents T cell activation and proliferation by inhibition of NF-KB, C-Myc, and pRb pathways. J Immunol. 2001;167:6021-30. https://doi.org/10.4049/jimmunol. 167.10.6021

21. Shibutani M, Maeda K, Nagahara H, Fukuoka T, Nakao S, Matsutani S, Hirakawa K, Ohira M. The peripheral monocyte count is associated with the density of tumor-associated macrophages in the tumor microenvironment of colorectal cancer: a retrospective study. BMC Cancer. 2017;17:404. https:// doi.org/10.1186/s12885-017-3395-1.

22. Ismail MM, Abdulateef NAB. Absolute monocyte count is superior than absolute lymphocyte count at day 28 as an independent prognostic factor in acute myeloid leukemia. Indian J Hematol Blood Transfus. 2019;35:100-8. https://doi.org/10.1007/s12288-018-0976-3.

23. Bar M, Othus M, Park HM, Sandhu V, Chen X, Wood BL, Estey E. Elevated lymphocyte count at time of acute myeloid leukemia diagnosis is associated with shorter remission. Leuk Lymphoma. 2015;56:3109-15. https://doi.org/10.3109/10428194.2015.1020060.

24. Sun YX, Kong HL, Liu CF, Yu S, Tian T, Ma DX, Ji CY. The imbalanced profile and clinical significance of T helper associated cytokines in bone marrow microenvironment of the patients with acute myeloid leukemia. Hum Immunol. 2014;75:113-8. https://doi.org/10.1016/j.humimm.2013.11.014.

25. Grivennikov SI, Greten FR, Karin M. Immunity, inflammation, and cancer. Cell. 2010;140:883-99. https://doi.org/10.1016/j.cell.2010.01.025

26. Liu Y, Cao X. The origin and function of tumor-associated macrophages. Cell Mol Immunol. 2015;12:1-4. https://doi.org/10.1038/cmi.2014.83.

\section{Publisher's Note}

Springer Nature remains neutral with regard to jurisdictional claims in published maps and institutional affiliations.

\section{Submit your manuscript to a SpringerOpen ${ }^{\circ}$ journal and benefit from:}

- Convenient online submission

- Rigorous peer review

- Open access: articles freely available online

- High visibility within the field

- Retaining the copyright to your article

Submit your next manuscript at $\boldsymbol{\nabla}$ springeropen.com 